\title{
PERWUJUDAN PARIWISATA BERKELANJUTAN MELALUI PEMBERDAYAAN MASYARAKAT LOKAL DI PULAU PAHAWANG, PESAWARAN, PROVINSI LAMPUNG
}

\author{
Embracing Sustainable Tourism through Local Community's \\ Empowerment in Pahawang Island, Pesawaran, Lampung Province
}

Isye Susana Nurhasanah ${ }^{1}$, Nava Neilulfar Alvi ${ }^{1}$ dan Citra Persada²

Diterima: 25 Januari 2017

Disetujui: 31 Mei 2017

\begin{abstract}
Abstrak: Pada saat ini, konsep perencanaan pariwisata telah berubah dan mengarah kepada pembangunan pariwisata berkelanjutan. Pergerakan yang lambat dalam pelaksanaan dari konsep tersebut menciptakan banyaknya pendekatan mengenai pariwisata berkelanjutan. Salah satu pendekatan yang dapat digunakan dalam pelaksanaan konsep pariwisata berkelanjutan adalah filosofi Cittaslow. Penelitian ini dilakukan dengan tujuan untuk mengindentifikasi pemberdayaan dan peran masyarakat dalam sektor pariwisata di Pulau Pahawang, Kabupaten Pesawaran, Provinsi Lampung, Indonesia. Pemberdayaan dan peran masyarakat lokal merupakan inti dari filosofi Cittaslow. Dari keterlibatan dua aspek tersebut dalam sektor pariwisata, akan diketahui bagaimana konsep pariwisata berkelanjutan dapat diterapkan. Pemberdayaan masyarakat lokal telah ditetapkan dalam konteks psikologis dan aspek sosial, khususnya dalam mengembangkan dan mengelola pariwisata. Penelitian ini menggunakan metode analisis kualitatif dan hasil dari penelitian ini akan mengungkapkan bahwa semakin efektif kerjasama antar pemerintah dan komunitas lokal baik pengusaha maupun masyarakat, maka akan semakin banyak kesempatan untuk mewujudkan pariwisata berkelanjutan.
\end{abstract}

\section{Kata kunci: pariwisata berkelanjutan, peran masyarakat, pemberdayaan masyarakat}

\begin{abstract}
Nowadays, the concept of Tourism Planning has shifting into sustainable tourism development. Because of the slow movement in implementing the concept, many alternative approaches have been offered. One of the alternative approaches to gain the sustainable development tourism is implementing the Cittaslow philosophy. This study aims to identify the local community's empowerment and involvement in tourism sector in Pahawang Island, Pesawaran Regency, Lampung Province, Indonesia. The local community involvement and empowerment are the essence ingredients of Cittaslow philosophy implementation. From the implication of those two aspects in tourism sector, this study will analyze through which sustainable tourism is better conduct. The local community empowerment was noted in the context of psychological and social aspects of local community empowerment, particularly for developing and managing tourism. This study used the qualitative method on the case of Pahawang Tourism in Pesawaran Regency, Lampung Province, Indonesia. The result reveals that, the more effective collaboration among government, local communities (businesses, and residents), the more chance to gain sustainable tourism.
\end{abstract}

Keywords: Sustainable tourism, community involvement, community empowerment, Pahawang, Lampung Province, Indonesia

\footnotetext{
${ }^{1}$ Program Studi Perencanaan Wilayah dan Kota, Institut Teknologi Sumatera

2 Jurusan Arsitektur, Fakultas Teknik, Universitas Lampung
} 


\section{PENDAHULUAN}

Pariwisata di Indonesia terus mengalami peningkatan dan ditandai dengan jumlah perjalanan wisatawan internasional dan domestik yang terus menunjukkan pertumbuhan yang positif (Kementerian Pariwisata, 2014). Pariwisata juga telah mengalami ekspansi dan diversifikasi berkelanjutan dan menjadi salah satu sektor ekonomi yang terbesar dan tercepat pertumbuhannya di dunia. Namun saat ini, semakin berkembangnya pariwisata justru menciptakan isu tersendiri di setiap wilayah terutama ketika pengembangan pariwisata lebih didominasi oleh nilai-nilai ekonomi. Hal ini menyebabkan kurangnya pengembangan nilai-nilai etika budaya, sosial, dan kearifan lingkungan dari masyarakat. Berbagai upaya telah dilakukan untuk mengembalikan kembali fungsi pariwisata yang sesungguhnya terutama yang selaras dengan gerakan pariwisata berkelanjutan.

Konsep keberlanjutan saat ini telah diterapkan di berbagai sektor pembangunan, tak terkecuali pariwisata. Tujuan dari penerapan konsep keberlanjutan dalam pariwisata tidak lain adalah memberikan dampak positif atau manfaat terhadap lingkungan dan ekonomi masyarakat lokal, serta berdampak positif pada lingkungan sosial maupun kebudayaan di wilayah tersebut. Produk pariwisata berkelanjutan diharapkan dapat dijalankan secara harmonis dengan lingkungan lokal, masyarakat, dan budaya. Kebijakan pembangunan pariwisata berkelanjutan terarah pada penggunaan sumber daya alam dan penggunaan sumber daya manusia untuk jangka waktu yang panjang (Baskoro, BRA\& Cecep Rukendi, 2008). Komunitas atau masyarakat dalam pariwisata berkelanjutan memegang peranan yang sangat penting dan harus dijadikan sebagai subjek pembangunan karena partisipasinya dalam pelaksanaan konsep keberlanjutan tesebut.

Lokasi Lampung yang strategis telah membuat wilayah tersebut sebagai wilayah pesisir yang potensial dikembangkan sebagai destinasi wisata yang berkelanjutan. Provinsi Lampung dikelilingi oleh Samudera Hindia di bagian Barat dan Selat Sunda di Bagian Timur, sehingga membuatnya kaya akan potensi ekowisata pesisir untuk dikembangkan, contohnya pantai-pantai, air terjun, hutan mangrove, budidaya terumbu karang, dan lainlain. Berdasarkan Rencana Strategis Pariwisata dan Ekonomi Kreatif Provinsi Lampung Tahun 2015-2019 Provinsi Lampung memiliki 7 Kawasan Unggulan Wisata, salah satunya adalah Kawasan Wisata Pulau Pahawang. Namun, rendahnya perencanaan dan manajemen pariwisata di Negara Indonesia pada umumnya dan di Provinsi Lampung khususnya menjadi isu persoalan yang masih dicari solusinya hingga saat ini. Dampak dari persoalan tersebut adalah banyaknya destinasi wisata yang belum dapat dikembangkan dan belum dapat memberikan kontribusi optimal untuk pendapatan wilayah, serta mengesampingkan kesejahteraan masyarakat lokal. Padahal apabila dilihat dari kondisi wilayah, Provinsi Lampung berada pada posisi yang strategis dan memiliki potensi wilayah pesisir yang dapat dikembangkan dengan konsep pariwisata berkelanjutan.

Sesuai dengan dokumen penataan ruang Kabupaten Pesawaran yang menerangkan bahwa tujuan penataan ruang Kabupaten Pesawaran adalah terwujudnya Kabupaten Pesawaran yang sejahtera berbasiskan sektor industri, agro dan pariwisata. Definisi dari sejahtera dalam Rencana Tata Ruang Wilayah (RTRW) Kabupaten Pesawaran tersebut adalah meningkatnya kualitas hidup masyarakat yang tercermin dari cukupnya fasilitas pendidikan, kesehatan, perdagangan dan jasa dan fasilitas lainnya lainnya. Sedangkan definisi pariwisata dalam meningkatkan kesejahteraan meliputi kegiatan pemeliharaan dan pemanfaatan sumber daya kelautan secara berkelanjutan dan berkualitas, seperti budidaya laut, perikanan tangkap, budidaya tambak, industri pengolahan hasil laut dan lainnya, transportasi dan pariwisata.

Menurut isu-isu yang telah dikemukakan di atas, penelitian ini membutuhkan suatu pendekatan yang menitikberatkan subyek penelitian pada masyarakat lokal. Oleh karena itu, penelitian ini akan menggunakan Cittaslow Philosophy dalam menentukan poin-poin 
kriteria pemberdayaan dan pelibatan komunitas yang akan diteliti. Cittaslow Philosophy digunakan karena latar belakang pembuatannya dinilai mendukung implementasi pariwisata berkelanjutan yang didapatkan dari filosofinya yang berbasis masyarakat lokal dan aktivitas yang mendorong masyarakat lokal dalam membangun kota mereka dengan tingkat kualitas hidup yang baik. Partisipasi komunitas dalam hal ini dapat meningkatkan rasa memiliki komunitas terhadap lingkungan tempat tinggalnya, membantu peran individu dalam komunitas yang lebih besar dan membantu pembentukan identitas individu dan juga masyarakat (Hatipoglu, 2015) (E. Park and S. Kim, 2015). Partisipasi aktif dari masyarakat lokal dalam perencanaan dan manajemen pariwisata merupakan hal yang penting dalam membangun pariwisata yang berkelanjutan, dan dalam hal ini pemberdayaan masyarakat lokal berada di posisi teratas dalam tingkatan partisipasi yang memastikan pelaksanaan yang lebih baik dalam mewujudkan pariwisata berkelanjutan di wilayah destinasi (Cole, 2006).

Berdasarkan paparan di atas, penelitian ini bertujuan untuk mengidentifikasi pemberdayaan masyarakat lokal dan pelibatannya dalam mewujudkan pariwisata berkelanjutan di destinasi wisata Pulau Pahawang, Kabupaten Pesawaran, Provinsi Lampung. Untuk mencapai tujuan penelitian ini digunakan beberapa bagian dari Cittaslow Philosophy dan penerapannya yang berkaitan dengan peningkatan pelibatan masyarakat lokal dan pemberdayaannya terkait dengan pengembangan pariwisata dari sudut pandang masyarakat lokal. Aspek-aspek yang difokuskan dalam penelitian ini adalah Pemberdayaan Psikologis (Psychological empowerment), Pemberdayaan Sosial (Social Empowerment), dan Pemberdayaan Politik (Political Empowerment).

\section{KONSEP CITTASLOW}

Konsep Cittaslow atau sering disebut sebagai slow city movement terinspirasi dari lambatnya pergerakan atau distribusi pangan (slow food movement) yang pernah terjadi di Italia pada tahun 1986. Cittaslow menerapkan konsep ini pada kota berskala kecil dengan jumlah penduduk kurang dari 50.000 orang dan kota yang memenuhi kriteria dari 7 (tujuh) kebijakan wilayah yaitu:

1. Lingkungan

2. Infrastruktur dan Transportasi

3. Lansekap Kota

4. Kualitas Hidup

5. Ekonomi, Industri dan Pariwisata

6. Kebudayaan, Sejarah dan Keterlibatan Sosial

7. Kerjasama

Penelitian sebelumnya telah mengidentifikasi mengenai nilai-nilai dasar yang terkandung dalam Cittaslow Philosophy (Mayer, H., \& Knox, P. L., 2009), yaitu:

1. Melestarikan dan mempromosikan keistimewaan atau identitas lokal

2. Menciptakan masyarakat yang sejahtera melalui ketersediaan pangan

3. Membantu perkembangan hidangan lokal

4. Mendorong perkembangan kebudayaan dan sejarah lokal

5. Mendukung perkembangan produk lokal, produk petani dan usaha menengah

6. Perkembangan yang mengarah kepada keberlanjutan lingkungan

7. Meningkatkan hubungan antar masyarakat, swasta dan pemerintah lokal

8. Melibatkan partisipasi masyarakat lokal dalam pengambilan keputusan

Cittaslow Philosophy tidak hanya mendorong perkembangan kondisi sosial, lingkungan dan keberlanjutan ekonomi bagi masyarakat, namun juga mendukung pemerintah daerah untuk dapat mengoreksi kinerja pemerintah terutama dalam hubungannya untuk meningkatkan kualitas hidup masyarakat (Presenza, A., Abbate, T., \& 
Micera, R., 2015). Cittaslow Philosphy dalam penerapannya lebih mengutamakan pada locality baik dari segi wilayah maupun masyarakat lokal dalam konteks pembangunan berkelanjutan. Cittaslow Philosophy diharapkan dapat mengurangi dampak negatif dari isu globalisasi pada suatu wilayah dengan meningkatkan sense of place melalui kekhasan wilayah dan identitas lokal. Dalam sektor pariwisata sendiri, hal ini dapat menjadi salah satu cara dalam mewujudkan pariwisata berkelanjutan. Selain menitikberatkan pada kekayaan lokal, konsep ini juga mendorong adanya keberlanjutan ekonomi bagi usaha lokal. Cittaslow Philosophy dapat menjadi alternatif dalam pembangunan kota yang berkelanjutan yang berfokus pada kesejahteraan sosio-ekonomi masyarakat lokal, perlindungan lingkungan dan pelestarian kebudayaan (Mayer, H., \& Knox, P. L., 2009)

Teori multidimensi dalam pariwisata telah berkembang terutama dalam hal partisipasi masyarakat. Menurut Friedmann (1992), kemiskinan merupakan konsekusi dari lemahnya kekuatan sosial, politik dan psikologis masyarakat. Pemberdayaan ekonomi mengarah kepada kontribusi yang merata pada setiap peningkatan ekonomi yang dihasilkan dari aktivitas pariwisata kepada masyarakat lokal (Scheyvens, 1999). Pemberdayaan ekonomi ini diharapkan dapat memberikan keuntungan ekonomi jangka panjang kepada masyarakat lokal dan mendorong terciptanya usaha kecil dan menengah. Sedangkan, pemberdayaan psikologis mengarah kepada peningkatan kebanggaan dan rasa memiliki terhadap wilayah tempat tinggal masyarakat serta meningkatkan kepercayaan diri masyarakat terhadap tradisi kebudayaan. Pemberdayaan psikologis ini diharapkan tidak hanya terpaku pada kebanggaan masyarakat namun juga dapat meningkatkan antusiasme masyarakat dalam memperkenalkan pengetahuan dan pengalaman kebudayaan kepada para pengunjung (Scheyvens, 1999). Kemudian, pemberdayaan sosial merujuk pada adanya terbentuknya integritas dari masyarakat lokal. Pemberdayaan sosial dapat mengarah kepada peningkatan kepercayaan terhadap identitas sosial yang dapat melestarikan kebudayaan dan sumber daya manusia pada wilayah tersebut (Timothy, 2007). Yang terakhir adalah pemberdayaan politik yang berupa peningkatan partisipasi masyarakat dalam memberikan aspirasi untuk pengambilan keputusan. Apabila masyarakat diberdayakan secara politik maka mereka juga dapat mengawasi aktivitas pariwisata secara mandiri dan aspirasi masyarakat dapat mengarahkan ke mana arah pembangunan pariwisata akan terus berjalan.

\section{METODE PENELITIAN}

Penelitian ini menggunakan pendekatan kualitatif dengan instrumen penelitian wawancara terhadap beberapa stakeholder terkait. Data primer yang dihasilkan didapat dengan melakukan in-depth interview dengan para stakeholder yang dinilai memiliki pengalaman dan pengetahuan banyak terkait pengembangan di Pahawang. In depthinterview tersebut dilakukan kepada 4 stakeholder yaitu Dinas Pariwisata Kabupaten Pesawaran, Lembaga Swadaya Masyarakat (LSM) Mitra Bentala, tokoh masyarakat, dan akademisi. Para narasumber tersebut ditentukan dengan metode purposive sampling dan snowball sampling. Adapun untuk mendapatkan internal validity dari para narasumber maka hasil dari wawancara kemudian ditranskrip sesuai aslinya lalu ditunjukkan kembali kepada narasumber untuk mengkonfirmasi validitas jawaban dan informasi yang telah disampaikan.

Metode analisis yang digunakan dalam penelitian ini adalah Qualitative Content Analysis, yang terdiri dari emphasises emerging categorie dan recognises the significance for understanding the meanings. Adapun 4 step yang akan dilakukan untuk dapat menganalisis data setelah data hasil wawancara didapatkan adalah: (1) identifying initial 
themes and constructing an index, (2) labeling the data; (3) sorting the data; and (4) summarizing or synthesizing the data (E. Park and S. Kim, 2015).

\section{HASIL TEMUAN DAN DISKUSI}

Pulau Pahawang awalnya merupakan salah satu pulau yang terisolasi di Provinsi Lampung. Sebelumnya, banyak terjadi perusakan lingkungan yang terjadi akibat penebangan hutan mangrove, pemboman ikan, putasium, dan penggunaan jaring pukat, yang kemudian menyebabkan rusaknya ekosistem pesisir pantai. Menurut data Badan Pusat Statistik (BPS) 2015, Pulau Pahawang berada pada Kecamatan Punduh Pidada dengan luas wilayah 113,19 $\mathrm{km}^{3}$, jumlah penduduk pada tahun 2014 mencapai 13.317 orang dan kepadatan penduduk mencapai 117,65 orang/km2. Pulau Pahawang berlokasi di Teluk Lampung dan memiliki 6 dusun, yakni: Dusun 1, Suwakbuah; Dusun 2, Peligetahan; Dusun 3, Jelarangan; Dusun 4, Kalangan; Dusun 5, Pahawang; Dusun 6, Cukunyai.

Tabel 1 Simpulan Identifikasi Tema dan Indeks

\begin{tabular}{|c|c|c|c|}
\hline No & Verbatim/items & Themes & Disempowerment/ Empowerment \\
\hline 1.1 & $\begin{array}{l}\text { Menjalankan usaha secara } \\
\text { mandiri }\end{array}$ & $\begin{array}{l}\text { 1.Ketidakpedulian } \\
\text { ketidakharmonisan }\end{array}$ & Ketidakberdayaan Sosial \\
\hline 1.2 & $\begin{array}{l}\text { Masyarakat tidak berhubungan } \\
\text { satu sama lain }\end{array}$ & & \\
\hline 1.3 & $\begin{array}{l}\text { Hubungan antar masyarakat } \\
\text { sangat sedikit }\end{array}$ & & \\
\hline 1.4 & $\begin{array}{l}\text { Tidak ada hubungan antara } \\
\text { pemerintah dan masyarakat } \\
\text { lokal }\end{array}$ & & \\
\hline 1.5 & Lingkungan terabaikan & & \\
\hline 2.1 & Kurang dilibatkan & 2.Kurangnya & Ketidakberdayaan Politik \\
\hline 2.2 & $\begin{array}{l}\text { Hampir tidak memberikan } \\
\text { dorongan }\end{array}$ & dorongan/motivasi & \\
\hline 2.3 & $\begin{array}{l}\text { Masyarakat dianggap kurang } \\
\text { berpengaruh }\end{array}$ & & \\
\hline 3.1 & $\begin{array}{l}\text { Kurangnya pihak yang dapat } \\
\text { mengurus pariwisata }\end{array}$ & $\begin{array}{l}\text { 3. Tidak ada pengakuan dari } \\
\text { stakeholder terkait (Dinas }\end{array}$ & \\
\hline 3.2 & $\begin{array}{l}\text { Potensi pariwisata yang tidak } \\
\text { dikembangkan }\end{array}$ & Pariwisata) & \\
\hline 4.1 & $\begin{array}{l}\text { Keputusan bersifat tidak } \\
\text { memiliki tujuan }\end{array}$ & $\begin{array}{l}\text { 4. Pengambilan keputusan } \\
\text { satu pihak }\end{array}$ & \\
\hline 4.2 & Tidak ada kekuasaan & & \\
\hline 4.3 & Tidak diberi kekuasaan & & \\
\hline 5.1 & $\begin{array}{l}\text { Mengadakan pertemuan yang } \\
\text { rutin }\end{array}$ & $\begin{array}{l}\text { 5. Kepedulian dan hubungan } \\
\text { yang terbangun antar }\end{array}$ & Kekuatan Politik \\
\hline 5.2 & $\begin{array}{l}\text { Mendengarkan aspirasi } \\
\text { masyarakat }\end{array}$ & stakeholder & \\
\hline 5.3 & $\begin{array}{l}\text { Memulai untuk membangun } \\
\text { hubungan yang kuat dengan } \\
\text { pemerintah } \backslash\end{array}$ & & \\
\hline 5.4 & $\begin{array}{l}\text { Memberikan dorongan kepada } \\
\text { masyarakat lokal }\end{array}$ & & \\
\hline 5.5 & $\begin{array}{l}\text { Mulai mendapat perhatian dari } \\
\text { pemerintah daerah }\end{array}$ & & \\
\hline 5.6 & $\begin{array}{l}\text { Masyarakat sudah mengetahui } \\
\text { apa yang mereka inginkan }\end{array}$ & & \\
\hline
\end{tabular}




\begin{tabular}{|c|c|c|c|}
\hline No & Verbatim/items & Themes & Disempowerment/ Empowerment \\
\hline 6.1 & Banyaknya kohesi dan koneksi & & \\
\hline 6.2 & $\begin{array}{l}\text { Keterlibatan masyarakat yang } \\
\text { tinggi }\end{array}$ & 6. Keselarasan sosial dan & Kekuatan Sosial \\
\hline 6.3 & Tumbuh bersama & kohesi masyarakat & \\
\hline 6.4 & $\begin{array}{l}\text { Menyatukan pengalaman } \\
\text { setiap masyarakat }\end{array}$ & & \\
\hline 6.5 & $\begin{array}{l}\text { Adanya relawan yang siap } \\
\text { untuk } \\
\text { masyarakat }\end{array}$ & & \\
\hline 6.6 & Gotong Royong & & \\
\hline 6.7 & $\begin{array}{l}\text { Masyarakat senang untuk } \\
\text { terlibat atau berpartisipasi }\end{array}$ & & \\
\hline 6.8 & Adanya kontribusi nyata & & \\
\hline 6.9 & $\begin{array}{l}\text { Menempatkan sesuatu untuk } \\
\text { masyarakat }\end{array}$ & & \\
\hline 6.10 & $\begin{array}{l}\text { Maju bersama untuk } \\
\text { mendapatkan dukungan }\end{array}$ & & \\
\hline 6.11 & $\begin{array}{l}\text { Tidak berorientasi pada } \\
\text { uang/keuntungan }\end{array}$ & & \\
\hline 7.1 & $\begin{array}{l}\text { Meningkatkan pelayanan } \\
\text { sosial }\end{array}$ & 7. Pengembangan komunitas & \\
\hline 7.2 & $\begin{array}{ll}\text { Pengadaan } & \text { program } \\
\text { pembinaan } & \end{array}$ & & \\
\hline 7.3 & $\begin{array}{l}\text { Mendorong adanya produksi } \\
\text { lokal }\end{array}$ & & \\
\hline 8.1 & $\begin{array}{l}\text { Memprioritaskan } \\
\text { keseimbangan }\end{array}$ & 8. Kualitas hidup & \\
\hline 8.2 & Membeli produk lokal & & \\
\hline 8.3 & Kualitas hidup & & \\
\hline 8.4 & Pola pikir dan gaya hidup & & \\
\hline 8.5 & Mempromosikan Pahawang & & \\
\hline 9.1 & $\begin{array}{lll}\text { Bangga } & \text { dengan } & \text { lingkungan } \\
\text { mereka } & & \\
\end{array}$ & $\begin{array}{l}\text { 9. Harga diri dan Kebanggaan } \\
\text { masyarakat }\end{array}$ & Kekuatan Psikologis \\
\hline 9.2 & Selalu memiliki ide yang positif & & \\
\hline 9.3 & $\begin{array}{l}\text { Bangga menjadi bagian dari } \\
\text { Pahawnag }\end{array}$ & & \\
\hline 9.4 & Pembicaraan yang positif & & \\
\hline 9.5 & $\begin{array}{l}\text { Memiliki rasa bangga untuk } \\
\text { memiliki }\end{array}$ & & \\
\hline 9.6 & Meningkatkan kebanggaan & & \\
\hline 9.7 & Kepercayaan diri & & \\
\hline 10.1 & Membeli produk lokal & 10. Keuntungan & Kekuatan Ekonomi \\
\hline 10.2 & $\begin{array}{l}\text { Keuntungan ekonomi untuk } \\
\text { jangka waktu yang panjang }\end{array}$ & jangka panjang & \\
\hline 10.3 & $\begin{array}{l}\text { Diharapkan dapat berdampak } \\
\text { positif bagi ekonomi wilayah }\end{array}$ & & \\
\hline
\end{tabular}

Berdasarkan hasil wawancara dengan para stakeholder yang telah diklasifikasi berdasarkan tema dan daftar indeks diatas, didapatkan beberapa poin yaitu:

1) Pariwisata berkelanjutan melalui pemberdayaan dan penguatan peran komunitas lokal di Pahawang dapat dicapai melalui pengetahuan konsep fasilitas berdasarkan kebutuhan dan pengetahuan lokal terhadap lingkungannya. Sebelum ada intervensi berupa 
asistensi intensif dari NGO Mitra Bentala, masyarakat lokal di Pulau Pahawang dan sekitarnya tidak begitu peduli terhadap lingkungan tempat yang mereka tinggali. Mereka cenderung beraktivitas dan berkonsentrasi dengan pekerjaannya masing-masing, tanpa terlalu memperhatikan lingkungan. Ketika masyarakat lokal telah dapat sadar akan pentingnya menjaga lingkungan, terlebih ketika mereka berada di kawasan pesisir maka ketika mereka telah mampu dan menyadari pentingnya menjaga habitat mangrove, terumbu karang yang ada di lautan sekitar mereka, hal tersebut menjadi modal dasar untuk dapat memberi nilai lebih terhadap pemanfaatan lingkungannya.

2) Komunitas berperan penting dalam pengambilan keputusan akhir yang berhubungan dengan peningkatan kualitas hidup mereka dan termasuk dimensi lingkungan. Inisiai dari masyarakat dalam membahas dan mendiskusikan terkait hal-hal yang dapat meningkatkan kulitas hidup mereka akan lebih menginternalisasi dan menjawab kebutuhan mereka. Terlebih ketika kondisi rendahnya perhatian pemerintah daerah atau lambatnya pemerintah dalam merespon kebutuhan-kebutuhan masyarakat tersebut.

3) Kemudian kondisi koordinasi yang lemah antara komunitas lokal dengan pemerintah. Minimnya perhatian pemerintah terhadap kebutuhan infrastruktur dan dukungan kebijakan terkait pengembangan kawasan pariwisata Pahawang yang telah diinisiasi masyarakat local.

4) Tidak adanya regulasi kuat yang mengikat dari pemerintah terkait penyelenggaraan pariwisata yang ramah lingkungan atau ecotourism.

Temuan di atas sesuai dengan pernyataan yang dikemukakan dalam penelitian sebelumnya oleh Jovicic dalam Kim 2015:

"As an alternative to the practice of enhancing the socially sustainable aspect, community empowerment suits tourism development as it responds to the subjective needs of local communities. In this respect, the importance of the quality of life and the conservation of natural and social resources are highlighted."

Pembangunan pariwisata pesisir yang berkelanjutan ternyata merupakan pilihan yang baik untuk mendapatkan manfaat lebih dari lokasi tempat tinggal warga di Pulau Pahawang dan sekitarnya. Pemberdayaan masyarakat merupakan solusi yang tepat dalam penanganan lingkungan yang baik dimana ketika mereka telah sadar akan pentingnya menjaga lingkungan dan habitat pesisir di sekeliling mereka, mereka akan merasakan sendiri manfaat lebih yang dapat mereka terima dari upaya melestrakan lingkungan pesisir tersebut. Di Pahawang sendiri, ketika masyarakat lokal telah dapat melestarikan mangrove dan terumbu karang yang ada di lingkungan mereka, mereka dapat memetik manfaat lebihnya. Aktivitas pelestarian mangrove dan terumbu karang tersebut dapat dijadikan wisata edukasi dan konservasi yang menarik minat wisatawan dalam dan luar negeri untuk datang.

Dengan adanya aktivitas pariwisata tersebut, hingga saat ini warga Pahawang mendapatkan manfaat lebih berupa kualitas hidup yang baik dari sisi ekonomi, dan kebebasan waktu. Sebelum menjadi daerah wisata mayoritas penduduk bermatapencaharian sebagai petani dan nelayan. Waktu kerja yang tidak tentu membuat leisure time penduduk Pulau Pahawang sangat sedikit dan membutuhkan waktu hingga berbulan-bulan untuk kembali ke rumah. Sedangkan setelah menjadi kawasan wisata mereka bisa tinggal lebih lama di tempat tinggal mereka dan mengelola bisnis usaha penunjang pariwisata dengan penghasilan yang lebih besar dari mata pencaharian sebelumnya. Pulau Pahawang menawarkan wisata dengan konsep wisata tinggal dan menetap sementara waktu (live in) sehingga dalam aktivitasnya wisatawan masyarakat dapat berinteraksi secara langsung. Periode menetap sementara waktu sangat disesuaikan dengan kebutuhan dan keinginan dari wisatawan. Adanya konsep tinggal sementara waktu 
dan berinteraksi dengan masyarakat merupakan bentuk implementasi dari upaya penguatan ekonomi lokal secara mandiri sesuai dengan pilar local economic vitality.

Hal tersebut dibuktikan berdasarkan paparan stakeholder dalam hasil wawancara, salah satunya paparan tokoh masayarakat Pahawang, Pak Isnen:

"Masyarakat jadi lebih produktif, artinya sekarang ini dengan banyaknya pengunjung mereka selalu siap. Jadi semangat hidup untuk maju itu besar. Kemudian dari inisiatif mereka untuk terus membersihkan lingkungan. Sebelumnya, mereka itu kesibukannya masing-masing, ada yang melaut ada yang berkebun, jadi buruh kebun gitu bu. Ada juga yang buruh kebun, kalau bahasa sininya

babang bu, artinya keluar kampung untuk berbulan-bulan, ke Jawa kemudian pulang setelah

berlayar. kemudian yang ibu-ibu ya bantu buruh "ngoret", membersihkan kebun, bersih-bersih rumah. Sabtu-minggu mereka bersiap untuk sambut wisatawan. kl lagi kosong ya kadang bersihkan kapal. jadi kalau bercandaanya di sini, kalau bisa di kalender tuh tanggal merah semua biar pada liburan"(Isnen, 2016)

Selanjutnya, berdasarkan hasil yang diteliti dari aspek psychological dan social empowered dari komunitas lokal di dapatkan bahwa dengan perubahan kondisi kualitas hidup yang masyarakat lokal terima,serta manfaat lebih dari kawasan tempat tinggal mereka yang menjadi daerah tujuan wisata, masyarakat lokal memiliki rasa percaya diri bahwa mereka memiliki kapasitas untuk mengelola pariwisata berbasis lingkungan secara swadaya. Selama menetap di Pulau Pahawang, wisatawan akan hidup berdampingan dengan masyarakat Pulau Pahawang, sehingga diharapkan wisatawan dapat merasakan secara langsung bagaimana aktivitas masyarakat sekaligus merasakan adanya kekerabatan sosial, kekayaan budaya serta kearifan lingkungan yang dimiliki oleh masyarakat Pulau Pahawang. Hal tersebut merupakan salah satu implementasi dari environmental responsibility dan cultural sensitivity. Hal ini sesuai dengan keterangan yang dipaparkan pihak stakeholder yang diwawancara:

"Jelas mereka merasa bangga. Artinya kalau melihat lokasi Pahawang sendiri, memang ada dua dusun yang paling merasa pengaruhnya karena letaknya yang paling dekat dengan Pahawang, di depan pantai."(Isnen, 2016)

"Tadinya masyarakat itu tidak percaya diri sekarang jadi percaya diri, masalah rukun tetangga masih jalan, gotong royong juga masih jalan."(Mashabi, 2016)

Hal ini senada dengan hasil penelitian yang didapatkan oleh Scheyvens (2002) yang menyebutkan bahwa:

"The psychologically and Social empowered local community can have confidence in its ability to control its tourism resources more equitably in tourism planning, development and management (Scheyvens, 2002)

Kemudian hal terakhir yang diteliti dalam studi ini adalah keberadaan kordinasi antara pihak-pihak terkait dalam hal ini terutama masyarakat lokal dengan pemerintah. Keberlanjutan suatu pariwisata akan tercapai ketika ada bentuk pelibatan aktif dari masyarakat lokal dalam hal pengambilan keputusan dan perumusan kebijakan, sesuai dengan hasil penelitian yang diungkapkan Jamal \& Stronza (2009):

"Involvement of the local community is vital for creating an understanding between the government \& community about the appropriate \& sustainable use of local resources."

Dapat disimpulkan bahwa semakin baik kordinasi dan komunikasi antara masyarakat dan pemerintah maka semakin efektif dan optimal penyelenggaraan pariwisata yang berkelanjutan. Sayangnya, untuk pariwisata Pahawang kordinasi tersebut belum 
terlaksana dengan baik, pemerintah kurang kooperatif untuk mendukung masyarakat Pulau Pahawang dalam mengembangkan wisata konservasi dan pantai Pulau Pahawang. Peran pemerintah dalam hal ini penting dalam melegtimasi kebijakan yang dapat mendukung pariwisata Pahawang dengan masukan-masukan dari masyarakat lokal yang memang mengetahui benar apa saja kebutuhan dari Pahawang. Hal ini terlihat dari hasil wawancara seluruh stakeholder yang diwawancarai yang memiliki pendapat yang senada.

"Belum adanya peraturan-peraturan yang mengatur tentang pengelolaan wisata. Dan ditingkat SKPD belum terjadi sinergisitas, terkesan jalan masing-masing yang justru akan berakibat fatal dalam pengembangan wisata. Misalkan saja, masih banyak pihak yang melakukan alih fungsi lahan mangrove karena ada izinnya dan lain-lain." (Mashabi, 2016)

"Kendala besar di kesiapan pemerintah untuk berbagai peraturan yang berkaitan dengan pengembangan obyek wisata" (Persada, 2016)

"Dinas kita kan baru resmi berdiri akhir tahun 2015, jadi belum terlalu fokus. Dulu momennya ada momen olahraga, jadi kita fokus ke olahraga. Nah, bupati sekarang ini lebih fokus pada pariwisata, sehingga memang pariwisata mendapat perhatian. kemarinkan anggaran sudah dilaokasikan dr tahun 2015."(Jaka, 2016)

"Dari pemerintah provinsi, kabupaten, dinas pariwisata sekarang sudah mengakui keberadaan pariwisata Pahawang. Tapi memang gak semudah itu, dari awal ya kita bergerak sendiri."(Isnen,

Hal lain yang perlu diperhatikan dalam perkembangan Pulau Pahawang yakni Pulau Pahawang diketahui belum mengembangkan ekonomi lokal seperti dalam penyediaan cinderamata dan pertunjukan budaya. Padahal dengan adanya pertunjukan budaya maka masyarakat dapat menggambarkan kekayaan budaya, kearifan lokal, dan kearifan lingkungan di Pulau Pahawang. Kegiatan tersebut selain dapat memberikan dampak bagi pendapatan sekaligus dapat digunakan sebagai upaya pelestarian nilai-nilai budaya, sosial, dan kearifan lingkungan yang menggambarkan berjalannya environmental responsibility, cultural sensitivity, local economic vitality, serta experiental richness.

Berdasarkan input pengelolaan wisata melalui pemberdayaan masyarakat lokal di Pulau Pahawang tersebut kemudian dapat disusun sebuah Model Pengembangan Pariwisata Berkelanjutan yang dapat diterapkan di Pulau Pahawang. Model pengembangan tersebut digambarkan pada diagram berikut ini:

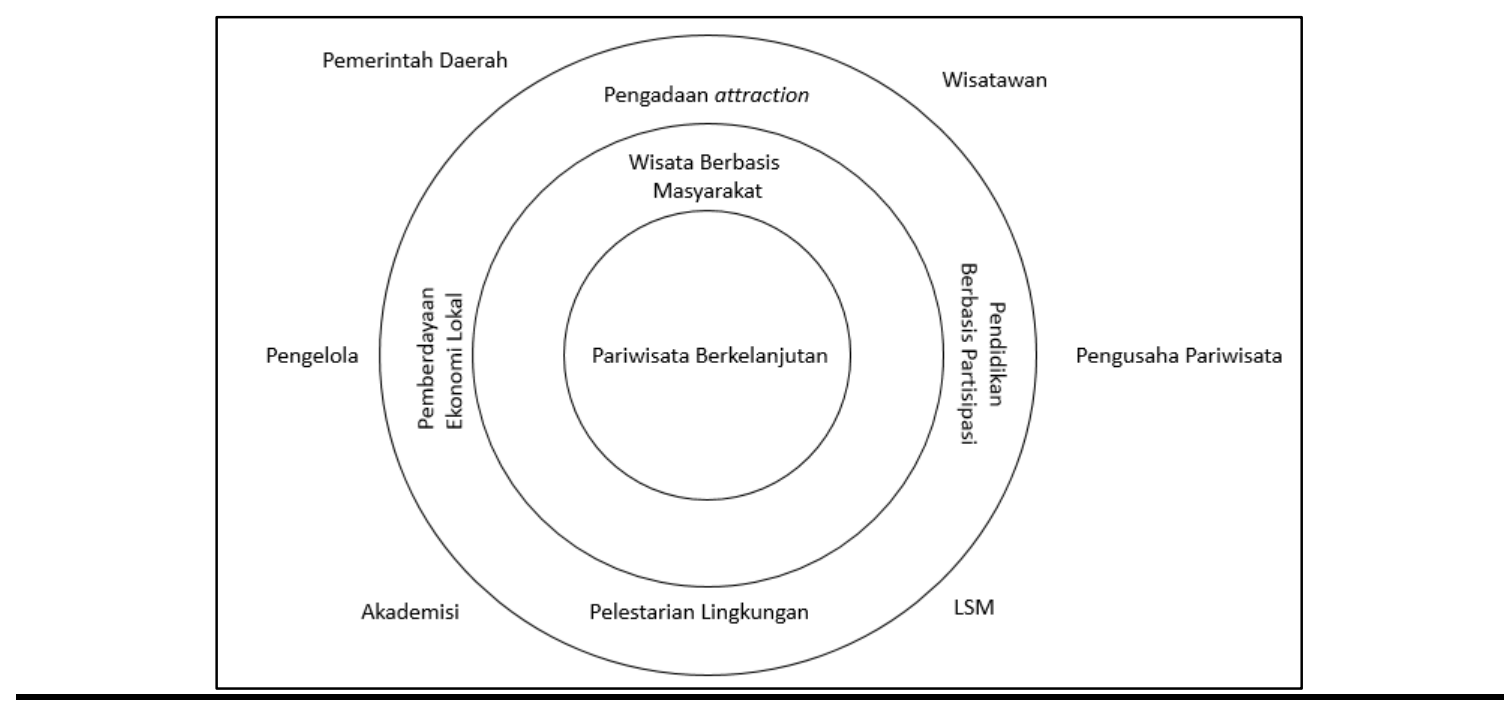

Gambar 1. Model Pengembangan Pariwisata Berkelanjutan yang dapat diterapkan di Pulau Pahawang 
Perwujudan pariwisata berkelanjutan melalui pemberdayaan masyarakat lokal merupakan salah satu pelaksanaan pembangunan yang dapat menggunakan Konsep Cittaslow. Hal ini didukung dengan konsep Cittaslow yang mentitikberatkan masyarakat baik dalam pemberdayaan maupun partisipasi masyarakat dalam meningkatkan kualitas hidup dan menjaga kelestarian lingkungan. Dalam perwujudan pariwisata berkelanjutan di Pulau Pahawang, ditemui bahwa masih kurangnya hubungan antara masyarakat lokal dan pemerintah yang menyebabkan terhambatnya kontribusi masyarakat terhadap perwujudan pariwisata berkelanjutan. Di sisi lain, adanya penerapan Cittaslow Pholosophy yaitu terciptanya keterlibatan masyarakat dalam perencanaan pariwisata sangat penting untuk dilakukan agar dapat membangun kesepahaman antara pemerintah dan masyarakat dalam mengelola sumber daya lokal . Pendekatan ini tidak hanya menuntut untuk mengelola sumber daya lokal secara efektif, namun juga diharapkan dapat menciptakan nilai dan memberdayakan masyarakat agar dapat menjalankan aktivitas pariwisata dengan baik.

Pada penelitian lain, dijelaskan bahwa wisata berbasis masyarakat mengarah kepada usaha lokal dalam merencanakan, mengembangkan, dan mengelola potensi pariwisata yang ada di wilayah mereka (Murphy, 1983). Usaha masyarakat tersebut kemudian akan meningkatkan ketertarikan masyarakat terhadap pariwisata dan pengelolaan sumber daya alam yang potensial disekitar mereka. Peneliti telah menemukan adanya relevansi dari wisata berbasis masyarakat terhadap daya dukungnya untuk memenuhi kebutuhan masyarakat lokal dengan adanya keuntungan ekonomi, partisipasi dan keterlibatan masyarakat, serta rasa untuk memiliki atau sense of ownership dari masyarakat (Matarrita-Cascante, David., Brennan, Mark Anthony., Luloff, A. E., 2010). Dengan adanya pengelolaan sumber daya oleh masyarakat lokal, maka hal tersebut akan mengarah kepada tebentuknya sustainable communities. Dengan demikian, masyarakat lokal dapat berpartisipasi secara efektif dan berperan dalam proses pengambilan keputusan. Masyarakat juga dapat berinteraksi dengan pihak lain seperti pemerintah, swasta, LSM, dan pendatang. Masyarakat merupakan faktor yang paling penting dalam proses pengembangan pariwisata di suatu wilayah, karena masyarakat berperan sebagai agen promosi yang bertujuan membangun interaksi dan partisipasi dalam pengambilan keputusan serta pengelolaan sumber daya.

Pada kasus di Pulau Pahawang, pemberdayaan masyarakat sudah dilakukan oleh Lembaga Swadaya Masyarakat (LSM) Mitra Bentala dan sudah menunjukan pengembangan yang positif terhadap kondisi sosial di wilayah tersebut. Masyarakat sedikit demi sedikit telah memiliki rasa kebanggaan dan rasa memiliki terhadap Pulau Pahawang sehingga kemudian tercipta keinginan untuk dapat melestarikan lingkungan di wilayah tersebut. Hal ini didukung dengan adanya aktivitas masyarakat dalam menjaga kelestarian hutan mangrove, keberadaan terumbu karang, dan lain-lain. Selain itu, masyarakat juga sudah dapat menjalankan aktivitas pariwisata yang ada di Pulau Pahawang dan meningkatkan eksistensi wisata bahari di Pulau Pahawang.

Namun, kontribusi masyarakat dalam mengembangkan pariwisata di Pulau Pahawang masih terhambat karena kurangnya peran pemerintah terhadap pemberdayaan masyarakat dan masih minimnya peraturan daerah yang mengatur tentang penerapan tiga pilar pembangunan pariwisata berkelanjutan yaitu ekonomi, social dan lingkungan. Hal ini menyebabkan perwujudan konsep pariwisata berkelanjutan belum bisa dilakukan di Pulau Pahawang karena tidak adanya hubungan yang baik antar para subyek pembangunan. Hal ini menjadi isu yang perlu diperhatikan karena pengambilan keputusan masih dilakukan oleh institusi politik saja secara top down dan tidak semua stakeholder dapat berperan dalam pengambilan keputusan tersebut. Karena kurangnya hubungan antar stakeholder tersebut mengakibatkan tidak maksimalnya perkembangan yang terjadi di Pulau Pahawang. Penelitian ini menunjukan bahwa pemberdayaan dan keterlibatan masyarakat 
lokal merupakan langkah yang tepat dalam meningkatkan peran masyarakat dalam pengambilan keputusan dan perwujudan pariwisata berkelanjutan di Pulau Pahawang.

\section{KESIMPULAN}

Berdasarkan hasil temuan dan diskusi dari penelitian ini, dapat dikatakan bahwa pemberdayaan masyarakat lokal di Pulau Pahawang telah berjalan sejak lama, dari 20 tahun yang lalu dimana masyarakat lokal berada dalam kondisi ketidakberdayaan sosial dan politik. Ketidakberdayaan sosial ditunjukkan dengan sikap masyarakat yang umumnya tidak peduli dengan lingkungannya dan cenderung sibuk dengan urusan masing-masing. Kemudian ketidakberdayaan politik ditunjukkan dari kurangnya pelibatan masyarakat dalam pengambilan keputusan terkait pembangunan lingkungannya

Setelah program pemberdayaan masyarakat di Pulau Pahawang, beberapa aspek mulai terbangun seperti: kekuatan sosial yang meningkat dilihat dari peningkatan dalam keselarasan sosial dan kohesi masyarakatnya, adanya pengembangan komunitas, dan peningkatan kualitas hidup masyarakat lokal secara umum, kekuatan politik yang meningkat dilihat dari kepedulian untuk terlibat dalam pengambilan keputusan terkait lingkungannya dan hubungan yang terbangun antar stakeholder dilihat dari sisi kemauan yang meningkat dalam hal konsensus untuk memutuskan pembangunan dan pelestarian lingkungannya, kekuatan psikologis yang meningkat dilihat dari peningkatan rasa memiliki, harga diri dan kebanggaan masyarakat terhadap lingkungannya, kekuatan ekonomi yang meningkat dilihat dari prospek keuntungan ekonomi jangka panjang yang mereka usahakan bersama di lingkungannya yang dijadikan destinasi wisata.

Namun, peran masyarakat untuk membangun kawasan mereka menjadi kawasan pariwisata yang berkelanjutan terhambat oleh sulitnya meyakinkan pemerintah setempat untuk dapat mendukung pariwisata yang mereka bangun tersebut dari sisi kebijakan. Pemerintah masih terkesan bertindak sporadic dan tidak mengenai duduk persoalan ketika melaksanakan program-program untuk mendukung pariwisata Pahawang karena minimnya kordinasi dan komunikasi dengan masyarakat lokal.

Secara garis besar, kesimpulan dari penelitian ini dapat digambarkan dalam 4 poin berikut ini, yaitu: Proses pemberdayaan dan keterlibatan masyarakat dapat menjadi penggerak dalam menerapkan pariwisata berkelanjutan di Pulau Pahawang karena dapat meningkatkan antusiasme masyarakat dalam memperkenalkan pengetahuan dan pengalaman kebudayaan kepada para pengunjung. Selain itu hal tersebut juga mengarah peningkatan kepercayaan terhadap identitas sosial yang dapat melestarikan kebudayaan dan sumber daya manusia pada wilayah tersebut. Adanya sense of belonging pada masyarakat akan menciptakan kesadaran masyarakat terhadap kelestarian lingkungan. Kolaborasi yang efektif antara pemerintah, masyarakat lokal, dan stakeholder lain dapat meningkatkan kesempatan untuk mewujudkan pariwisata berkelanjutan di Pulau Pahawang. Minimnya peran pemerintah dalam mengeluarkan kebijakan untuk mengelola ecotourism menghambat perwujudan pariwisata berkelanjutan di Pulau Pahawang. Hal ini ditandai dengan tidak adanya peraturan daerah yang menyediakan aturan tentang penerapan tiga pilar pembangunan pariwisata berkelanjutan, ekonomi, sosial, dan lingkungan. 


\section{DAFTAR PUSTAKA}

Baskoro, BRA\& Cecep Rukendi. (2008). Membangun Kota Pariwisata Berbasis Komunitas; Sebuah Kajian Teoritis. Jurnal Kepariwisataan Indonesia Departemen Kebudayaan dan Pariwisata Indonesia, vol. 3 No I Maret, 5-7.

Butler, R. (1975). Tourism as An Agent of Social Change, Tourism as a Factor in National and Regional Development. Occasional Paper 4 Peterborough Ontario Department of Geography Trent University.

Chaerun Nisa dan Muliani. (2008). Pengaruh Aktivitas Pariwisata Terhadap Keberlanjutan Sumberdaya Wisata Pada Obyek Wisata PAl, Kabupaten Tegal. Semarang: Universitas Diponegoro.

CIFOR. (2004). Laporan Studi CIFOR: Pembangunan Pariwisata Berbasis Masyarakat. Jakarta.

Cole, S. (2006). "Information and empowerment: The keys to achieving sustainable tourism. Journal of Sustainable Tourism, vol. 14(6), 629-644 .

E. Park and S. Kim. (2015). "The potential of Cittaslow for sustainable tourism development: enhancing local community's empowerment,". Tourism Planning Development, vol. 8361, 1-19.

Hatipoglu, B. (2015). "Cittaslow": Quality of life and visitor experiences. . Tourism Planning \& Development, 12(1), 20-36.

Matarrita-Cascante, David., Brennan, Mark Anthony., Luloff, A. E. (2010). Community Agency and Sustainable Tourism Development, The Case of La Fortuna, Costa Rica.,. vol. 18 no. 6.

Mayer, H., \& Knox, P. L. (2009). Pace of life and quality of life: The slow city charter. In D. R. M. Sirgy, Pace of life and quality of life: The slow city charter. In , Community quality-of-life indicators: Best cases III (pp. 21-40). Dordrecht, the Netherlands: Springer.

Murphy, P. (1983). Tourism as a community industry. Tourism Management, Vol. 4(3), 180-193.

Presenza, A., Abbate, T., \& Micera, R. (2015). The Cittaslow Movement: Opportunities and Challenges for the Governance of Tourism Destinations. Tourism Planning \& Development.

Scheyvens, R. (1999). Ecotourism and the empowerment of local communities. Tourism Management, vol. 20(2), 245-249.

Timothy, D. J. (2007). Empowerment and stakeholder participation in tourism destination communities. In A. C. (Eds.), Tourism, Power and Space (pp. 199-216). London: Routledge. 